\title{
SEASONAL VARIATION IN SEMINAL QUALITY IN BRAZILIAN BOCACHICO (TELEOSTEI, CHARACIFORMES) ${ }^{1}$
}

\author{
JORDANA SAMPAIO LEITE ${ }^{2 *}$, MAYARA SETÚBAL OLIVEIRA-ARAÚJO², PRISCILA SILVA DE ALMEIDA- \\ MONTEIRO $^{2}$, CLÁUDIO CABRAL CAMPELLO ${ }^{2}$, ANA CLÁUDIA NASCIMENTO CAMPOS ${ }^{3}$, CARMINDA \\ SANDRA BRITO SALMITO-VANDERLEY ${ }^{2}$
}

\begin{abstract}
The Brazilian bocachico, Prochilodus brevis, is a rheophilic fish. Although there is evidence that this species shows reproductive seasonality in the wild, in captivity hormonal induction techniques allow semen sampling in different seasons. This study aimed to compare the kinetics, morphology and biochemical composition of the semen of Brazilian bocachico in captivity when hormonally induced to breed in the reproductive and non-reproductive seasons. During sampling spermiation was hormonally induced in breeders. The concentrations of total protein, glucose, fructose, triglyceride, calcium and chloride were evaluated with biochemical kits. The $\mathrm{pH}$ data (6.5 to 8.5) suggest semen requires alkaline conditions, as expected for freshwater fish. Seminal plasma contained more protein $\left(1.51 \pm 0.06 \mathrm{dL} \mathrm{g}^{-1}\right)$, glucose $\left(79.44 \pm 1.88 \mathrm{mg} \mathrm{dL}^{-1}\right)$ and triglycerides $\left(61.59 \pm 8.10 \mathrm{mg} \mathrm{dL}^{-1}\right)$ in the non-reproductive than the reproductive season, but calcium ions $\left(15.98 \pm 1.02 \mathrm{mg} \mathrm{dL}^{-1}\right)$ showed the opposite pattern. There was a significant seasonal difference in sperm morphology, with a higher percentage of normal sperm in the reproductive season. From these data it can be concluded that the physical, kinetic, morphological and biochemical characteristics of semen of captive Prochilodus brevis are influenced by reproductive season.
\end{abstract}

Keywords: Prochilodus brevis. Biochemistry. Reproduction. Seminal plasma. Fish.

\section{VARIAÇÃO SAZONAL DA QUALIDADE SEMINAL DE CURIMATÃ COMUM (TELEOSTEI, CHARACIFORMES)}

RESUMO - O curimatã comum Prochilodus brevis caracteriza-se como um peixe reofílico. Na natureza, esses animais apresentam sazonalidade reprodutiva, porém em cativeiro, técnicas de indução hormonal, permitem a coleta de sêmen em diferentes períodos do ano. Objetivou-se comparar a cinética, a morfologia e a composição física e bioquímica do sêmen de curimatã comum induzidos à reprodução em cativeiro com uso de hormônio, na estação reprodutiva e não reprodutiva. As concentrações de proteínas totais, glicose, frutose, triglicerídeo, cálcio e cloreto foram avaliadas através de kits bioquímicos e analisadas em espectrofotômetro. Os dados de $\mathrm{pH}$ do sêmen, sugerem condição alcalina do sêmen dentro do esperado para peixes de água doce $(6,5$ a 8,5$)$. A quantidade de proteínas totais $\left(1,51 \pm 0,06 \mathrm{~g} \mathrm{dL}^{-1}\right)$, glicose $\left(79,44 \pm 1,88 \mathrm{mg} \mathrm{dL}^{-1}\right)$ e triglicerídeos $(61,59 \pm$ $\left.8,10 \mathrm{mg} \mathrm{dL}^{-1}\right)$ no plasma seminal apresentaram uma maior concentração na estação não reprodutiva. Enquanto que o oposto foi verificado para os íons cálcio $\left(15,98 \pm 1,02 \mathrm{mg} \mathrm{dL}^{-1}\right)$. Houve diferença significativa, na morfologia do espermatozoide na estação reprodutiva, com uma porcentagem de espermatozoides normais superior em relação à estação não reprodutiva. Assim, pode-se concluir que características físicas, bioquímicas, cinéticas e morfológicas do sêmen de curimatã comum, mantidos em cativeiro, sofrem influência da estação reprodutiva.

Palavras-chave: Prochilodus brevis. Bioquímica. Reprodução. Plasma seminal. Peixe. 


\section{INTRODUCTION}

The Brazilian bocachico Prochilodus brevis is a species of fish originating in the watersheds of northeastern Brazil, and is also found throughout the southeast region (CHELLAPPA et al., 2009). The species is a promising candidate for fish farming due to its reproductive precocity, prolificacy and simple diet (FONTENELE, 1982; GURGEL et al., 2012).

The Brazilian bocachico is an annual spawning species and its reproductive period extends from December to May, coinciding with the rainy season in the state of Rio Grande do Norte, and some states of the Northeast region (GUEDES et al., 2005; NASCIMENTO et al., 2012). The species is rheophilic in habit, migrating towards the headwaters during the rainy season. Such migration is necessary because it promotes gonadal maturation and subsequent spawning. Thus both males and females of the species display reproductive seasonality (GOLPOUR et al., 2013). In the natural environment $P$. brevis reproduction is threatened by construction of reservoirs and by overfishing, mainly during the breeding season, since its roe are consumed by humans. In addition global climate change has modified the rainfall patterns in semi-arid regions, altering the reproductive process and endangering fish species, which may affect the functioning of ecosystems in the future (GURGEL et al., 2012).

Despite evidence of the reproductive seasonality of this species in the wild, hormonal induction can be used to collect semen throughout the year (LOPES et al., 2014). In captivity rheophilic fish do not reproduce naturally, due to the absence of stimuli triggered by piracema. Reproduction of rheophilic species in confined environments is only possible in two ways: simulation of natural conditions - increasing temperature and water level - or hormonal induction (VINATEA, 2004; ZANIBONI FILHO; WEINGARTNER, 2007).

To improve understanding of the influence of environmental changes on the reproduction of $P$. brevis it is necessary to investigate its reproductive biology, including the quality of seminal cells and plasma. The seminal plasma of fish consists of organic and inorganic components. The inorganic portion is involved in the inhibition and activation of sperm motility and the organic component in energy metabolism (RURANGWA et al., 2004). The composition of seminal plasma is influenced by several factors, including season (ARAMLI et al., 2013).

Biochemical analysis has been used measure seminal quality in equines, dogs and some species of fish such as Barbus barbus, Piaractus mesopotamicus, Piaractus brachypomus and Colossoma macropomum (GUASTI et al., 2012; AQUINO-CORTEZ et al., 2014; ALAVI et al., 2008; TAVARES-DIAS; MORAES, 2010; MELO-MACIEL, 2015), but there is no research on the quality of sperm from hormonally induced spermiation of Brazilian bocachico in and out of the reproductive season; in particular is no published biochemical analysis of seminal plasma.

Changes in basic physical and biochemical parameters can be used to elucidate the influence of environmental factors on the reproduction of Brazilian bocachico and thus provide information for conservation programs and improve understanding of the development of this species, as well as establishing whether high quality semen can be obtained throughout the year in captivity. The aim of this research was to compare the physical composition, kinetics, morphology and biochemistry of semen of Brazilian bocachico hormonally induced to reproduce in captivity in the reproductive and non-reproductive seasons.

\section{MATERIAL AND METHODS}

The project was approved by the Ethics committee for the use of animals of the State University of Ceará (4313324/2014). The experiment was carried out between 2014 and 2015; semen was sampled twice each during the reproductive season (rainy season, December to May) and non-reproductive season (dry season, June to November) of the species in the region (GUEDES et al., 2005; NASCIMENTO et al., 2012). Monthly average data on precipitation, temperature and solar radiation were obtained from FUNCEME (Cearense Foundation of Meteorology and Water Resources) to provide information on environmental variations during the experiment.

Thirteen Brazilian bocachico males originating from the Fish Reproduction Biotechnology Laboratory, located at the Itaperi campus of the State University of Ceará, Fortaleza, Ceará, Brazil ( $3^{\circ} 47$ 46.2 "S; $38^{\circ} 33$ '30 .1 'W) were used. They were relatively homogeneous with respect to size and weight $(20.60 \pm 0.31 \mathrm{~cm}$, $126.92 \pm 5.71 \mathrm{~g})$ and release of semen when submitted to mild abdominal pressure.

At the start of the study the fish were fitted with sterile microchips (Veri-Tag) to enable individual monitoring. The animals were kept in $7,100 \mathrm{~L}$ fiberglass tanks at an average temperature of $27{ }^{\circ} \mathrm{C}$ with a dissolved oxygen concentration of $8 \mathrm{mgL}^{-1}$. They were fed daily with commercial feed containing $32 \%$ crude protein at the rate of $3 \%$ of live weight per day, divided into two meals (NUNES et al., 2016).

To induce spermiation breeders were treated with pituitary extract from common carp (Cyprinus carpio): a single dose of $3 \mathrm{mg} \mathrm{kg}^{-1}$ of live weight was applied intracelomatically at the base of the pectoral fin. Eighteen hours later they were sedated with $22 \mathrm{~mL}$ of clove oil (Eugenol; Sigma-Aldrich) solution (eugenol 1: alcohol 10: water 10000), to 
facilitate handling and reduce stress.

After sedation the fish were placed on a sponge and their eyes were covered with a damp cloth. Then their identity chip was read, furcal length $(\mathrm{cm})$ and weight $(\mathrm{g})$ were measured and semen was collected. To ensure that semen was not contaminated with water, blood, feces or urine the genital orifice was cleaned with a paper towel. Semen was collected by application of gentle abdominal pressure in the anteroposterior direction using sterile, graduated syringes and transferred to sterile polyethylene tubes. Semen samples were stored on ice in a thermal box at a temperature of approximately $4{ }^{\circ} \mathrm{C}$ for no more than 30 minutes before processing and analysis (NUNES et al., 2016).

Semen volume $(\mathrm{mL})$ was measured at the time of collection using graduated syringes. Semen $\mathrm{pH}$ was measured with $\mathrm{pH}$ strips (MERCK-Germany).

To measure sperm concentration semen samples were fixed in 4\% formol-citrate solution in the proportion of 1:4000 (LEITE et al., 2013) and $20 \mu \mathrm{L}$ aliquots of this solution were deposited in a Neubauer chamber and analyzed under an optical microscope with a $40 \mathrm{x}$ objective lens.

Spermatic kinetics were evaluated by placing aliquots consisting of $1 \mu \mathrm{L}$ of semen homogenized with $100 \mu \mathrm{L}$ of activator solution (50 mM NaCl - $100 \mathrm{mOsm}$ ) in a Makler chamber. Evaluations were done using a computer-aided sperm analysis system (CASA), using Sperm Class Analyzer software (SCA, Microptics, version 5.0, Barcelona, Spain). The percentages of static spermatozoa and spermatozoa exhibiting fast, medium or slow movement were evaluated. Curvilinear velocity (VCL; in $\mu \mathrm{m} \mathrm{s}^{-1}$ ), straight line velocity (VSL; in $\mu \mathrm{m} \mathrm{s}^{-1}$ ) and mean path velocity (VAP; in $\mu \mathrm{m} \mathrm{s}^{-1}$ ) were evaluated.

Morphology was analyzed after fixation of the semen in $4 \%$ formol citrate solution in the ratio of 1:100 (semen: fixative) and staining with Bengal Rose in the ratio of 3:20 (dye: fixed semen). Two slides per animal were prepared and 100 spermatozoa were evaluated per slide according to the scheme proposed by Miliorini et al. (2011) adapted by Nunes et al. (2016). The readings were performed with the SCA program, using the 'Counter' module.

Seminal plasma was obtained by centrifuging (5430R centrifuge, Eppendorf) the semen at $500 \mathrm{~g}$ for two minutes then at $2500 \mathrm{~g}$ for 10 minutes at $4{ }^{\circ} \mathrm{C}$. The seminal plasma volume was measured with a syringe and the plasma was transferred to labeled sterile polyethylene tubes and stored in at $-80{ }^{\circ} \mathrm{C}$ until analysis.

Before biochemical analysis the semen aliquots were thawed at room temperature $\left(\sim 25^{\circ} \mathrm{C}\right)$. The overall protein concentration and concentrations of glucose, fructose, triglyceride, calcium and chloride were evaluated in duplicate using commercial kits (LABTEST ${ }^{\circledR}$ Diagnóstica S.A). These kits are routinely used for the in vitro diagnosis of human clinical conditions and are also suitable for biochemical analysis of seminal plasma (KAYA et al., 2002).

Sample readings were based on the formation of a colored product whose color intensity is proportional to the concentration. The kits are composed of three reagents used as follows: 1 - diluted in distilled water to calibrate the spectrophotometer; 2 - determines the color of the pattern; 3 - added to the plasma samples for reaction and color modification. Incubation in a water bath at $37^{\circ} \mathrm{C}$ was required to induce the reaction in analyses of overall protein concentration and glucose, fructose and triglyceride concentration. A spectrophotometer (SP-22, BioSpectro) was used to measure absorbance of the specific wavelength for each substance analyzed, according to the kit used.

For the statistical analysis, Shapiro-Wilks and Bartlett tests, were used to confirm the normality and homoscedasticity of the residue distribution, respectively. GLM ANOVA (fully randomized design) was carried out using the SAS Program, 2002, and post hoc comparisons of means were carried out using the Student-Newman-Keuls (SNK) test. In cases where the data did not show homogeneous variance across treatments even after transformation (e.g. volume of plasma, proteins, glucose, triglycerides, percentages of fast, medium and slow sperm, and head defects), the nonparametric Kruskal-Wallis test was used. The results are presented as mean \pm standard error of the mean and a significance level of 5\% was adopted.

\section{RESULTS AND DISCUSSION}

There were well-defined seasonal variations in environmental characteristics during the experimental period. In the reproductive season, from December to May, there was $171.88 \mathrm{~mm}$ precipitation, the mean maximum and minimum temperatures were $28.75{ }^{\circ} \mathrm{C}$ and $27.77{ }^{\circ} \mathrm{C}$ respectively and mean radiation was $1327.42 \mathrm{~kJ} \mathrm{~m}^{-2}$. In the period defined as the non-reproductive season monthly rainfall was much lower, at $43.38 \mathrm{~mm}$, the mean maximum and minimum temperatures were $33.38{ }^{\circ} \mathrm{C}$ and $27.70{ }^{\circ} \mathrm{C}$ and mean radiation was $1606.67 \mathrm{KJ} \mathrm{m}^{-2}$. These values are in line with expectations for these periods (GUEDES et al., 2005; MOURA et al., 2015).

Environmental variability in temperature and radiation has consequences for the allocation of energy for reproduction as it influences metabolism (WOOTTON, 1990). Temperature and radiation influence fishes' culture and reproductive capacity. The optimum temperature range for growth of hot water fish growth is 25 to $32{ }^{\circ} \mathrm{C}$. Environmental 
perturbations can cause, for example, acceleration of gonadal maturation and variations in the quality of gametes. Environmental changes limit the reproductive season and reproductive success of most fish species in Brazil and the rest of the world, which follow an annual cyclical reproductive behavior (VAZZOLER, 1996).

Data on weight and length $(N=13)$ and semen and seminal plasma of $P$. brevis are shown in Table 1. The mean size of the animals in the sample was $20.60 \pm 0.31 \mathrm{~cm}$, which is in line with the estimated range for reproducers, 16 to $23 \mathrm{~cm}$ (ARAÚJO; GURGEL, 2002).

There was a seasonal difference $(p<0.05)$ in semen $\mathrm{pH}$ (reproductive season: $8.23 \pm 0.08$, non-reproductive season: $8.65 \pm 0.07$; see Table 1 ).
These seasonal variations are within the expected range for freshwater fish, 6.5 to 8.5 (TABARES et al., 2005). In fish an alkaline seminal plasma $\mathrm{pH}$ increases the percentage of motile spermatozoa and their ability to fertilize oocytes (BILLARD, 1981).

There were no season differences in seminal volume or sperm concentration $(p>0.05)$, but there was a seasonal difference in seminal plasma volume $(p<0.05$, see Table 1$)$. It is known that seminal volume can be influenced by diet and hormonal induction of reproduction (SOLIS-MURGAS et al., 2011). In spite of the variation in seminal plasma volume, Brazilian bocachico maintained on a controlled diet show a good physiological response to hormonally induced spermiation is good throughout the year.

Table 1. Physical characteristics of animals and semen of Brazilian bocachico $(N=13)$; data are means \pm standard error of mean.

\begin{tabular}{ccc}
\hline Characteristics & Reproductive season & Non-reproductive season \\
\hline Fish weight $(\mathrm{g})$ & $126.92 \pm 5.71$ & $126.92 \pm 4.58$ \\
Furcal length $(\mathrm{cm})$ & $20.60 \pm 0.31$ & $20.15 \pm 0.30$ \\
Semen $\mathrm{pH}^{*}$ & $8.23 \pm 0.08$ & $8.65 \pm 0.07$ \\
Semen volume $(\mathrm{mL})$ & $0.44 \pm 0.09$ & $0.67 \pm 0.07$ \\
Plasma volume $(\mathrm{mL})^{*}$ & $0.15 \pm 0.03$ & $0.37 \pm 0.07$ \\
Sperm concentration $\left(\mathrm{sptz} \mathrm{x} \mathrm{109} \mathrm{mL}^{-1}\right)$ & $45.67 \pm 3.44$ & $48.26 \pm 3.63$ \\
\hline
\end{tabular}

Legend: * seasonal difference $(p<0.05)$.

There was a seasonal difference $(p<0.05)$ in the overall protein concentration of seminal plasma, which was higher in the non-reproductive season (1.51 $\pm 0.06 \mathrm{~g} \mathrm{dL}^{-1}$, Table 2). These proteins play a key role in the prolongation of sperm viability in teleostean fish and are found in higher concentrations in non-reproductive periods (LAHNSTEINER et al., 2004). Overall seminal plasma protein concentration is considered an important index of seminal quality (SHALIUTINA-KOLESOVA et al., 2016).

Glucose and fructose levels are important biochemical parameters, as these sugars protect the spermatozoan membrane (MAISSE, 1996). Glucose, fructose and triglycerides are the main energy sources for spermatozoa (LAHNSTEINER et al., 1993). The concentration of glucose in the seminal plasma was higher in the non-reproductive season (Table 2), as Melo-Maciel (2015) observed in the seminal plasma of Tambaqui. The concentration of glucose in the seminal plasma is greater in periods when the testes have a high energy demand due to spermatogenesis or lipid synthesis, both of which are fundamental to preparation for migration (SOENGAS et al., 1993). There was no seasonal difference in fructose concentration $(p>0.05)$.
The concentration of triglycerides in seminal plasma was higher (Table 2) during the non-reproductive season $\left(61.59 \pm 8.10 \mathrm{mg} \mathrm{dL}^{-1}\right)$, which is consistent with the fact that these lipids serve as an energy source for spermatozoa during the non-reproductive periods (LAHNSTEINER et al., 1993). Triglycerides are important for prolongation of sperm viability and have a positive influence on sperm motility and fertility (LAHNSTEINER et al., 2009). Triglyceride concentrations fall during the reproductive period $\left(9.76 \pm 0.95 \mathrm{mg} \mathrm{dL}^{-1}\right)$ because high concentrations may have deleterious effects on spermatogenesis (BEER-LJUBIC et al., 2009).

Most of the ions in the seminal plasma of fish are involved in the regulation of sperm motility, since they act on intra- or extra-cellular osmolarity (ALAVI; COSSON, 2006). Calcium and magnesium ions are the main determinants of the osmolarity of the seminal plasma (SECER et al., 2004). In our sample the concentration of calcium ions was higher in the reproductive season $\left(15.98 \pm 1.02 \mathrm{mg} \mathrm{dL}^{-1}\right.$; Table 2). Halimi et al. (2014) showed that calcium ions are most needed in the reproductive season because spermatozoa need to be capable of reaching the oocyte and thus high concentrations of calcium in the semen ensure the fertilizing capacity of 
spermatozoa. The concentration of chloride ions is higher in Brazilian bocachico semen than in other teleosts (ARAMLI et al., 2013). There was no difference between the analyzed periods $(p>0.05$;
Table 2) with respect to chloride ion concentration; chloride is also positively related to motility, thus our fish produced good quality semen in both periods.

Table 2. Biochemical parameters of the seminal plasma of Brazilian bocachico $(N=13)$; data are means \pm standard error of the mean.

\begin{tabular}{ccc}
\hline Biochemistry & Reproductive season & Non-reproductive season \\
\hline Total proteins $\left(\mathrm{g} \mathrm{dL}^{-1}\right)^{*}$ & $0.63 \pm 0.31$ & $1.51 \pm 0.06$ \\
Glucose $\left(\mathrm{mg} \mathrm{dL}^{-1}\right)^{*}$ & $2.42 \pm 0.50$ & $79.44 \pm 1.88$ \\
Fructose $\left(\mathrm{mg} \mathrm{dL}^{-1}\right)$ & $121.86 \pm 5.91$ & $120.31 \pm 20.01$ \\
Triglycerides $\left(\mathrm{mg} \mathrm{dL}^{-1}\right)^{*}$ & $9.76 \pm 0.95$ & $61.59 \pm 8.10$ \\
Calcium $\left(\mathrm{mg} \mathrm{dL}^{-1}\right)^{*}$ & $15.98 \pm 1.02$ & $8.42 \pm 0.85$ \\
Chloride $\left(\mathrm{mEq} \mathrm{L}^{-1}\right)$ & $97.11 \pm 7.36$ & $105.13 \pm 3.61$ \\
\hline
\end{tabular}

Legend: *seasonal difference $(p<0.05)$.

The kinetics and morphology of the Brazilian bocachico spermatozoa were also analyzed (Table $3)$. There were no seasonal differences in motility parameters of motility $(p>0.05)$. This result is in agreement data from the genus Prochilodus, 89.0 and $99.8 \%$ (NASCIMENTO et al., 2012).

The sperm velocity parameters we chose are widely used as indicators of sperm quality. The only kinematic parameter to show a seasonal difference was VSL, with velocity being higher $(p<0.05)$ being higher in the non-reproductive season $\left(44.06 \pm 1.33 \mu \mathrm{m} \mathrm{s}^{-1}\right)$. This parameter is not widely measured in fish spermatozoa, as VCL is considered more relevant to sperm quality because the circular movement of spermatozoa facilitates their entrance to the oocyte, but a previous study found no seasonal variation in VCL (MORALES, 1986). Evidence that
VCL is independent of the season, as presented in this research, are important because there is evidence that sperm velocities are positively correlated with the fertilization rate in Prochilodus lineatus (VIVEIROS et al., 2010).

The sperm morphology data (Table 3) showed a seasonal difference $(p<0.05)$ in the percentage of normal spermatozoa, with the proportion of morphologically normal spermatozoa being in the reproductive season. This result highlights the reproductive seasonality of this species. Analysis of sperm morphology is fundamental to the determination of the seminal quality, since morphologically abnormal spermatozoa may be incapable of fertilization (MILIORINI et al., 2011).

Table3. Kinetic and morphological parameters of the semen of Brazilian bocachico $(N=13)$, mean \pm standard error of the means.

\begin{tabular}{ccc}
\hline Kinetics & Reproductive season & Non-reproductive season \\
\hline Mobile (\%) & $98.82 \pm 0.45$ & $98.59 \pm 0.45$ \\
Fast (\%) & $95.34 \pm 1.60$ & $94.66 \pm 0.67$ \\
Medium (\%) & $1.85 \pm 0.67$ & $2.20 \pm 0.31$ \\
Slow (\%) & $1.62 \pm 0.60$ & $1.33 \pm 0.17$ \\
Static (\%) & $1.18 \pm 0.45$ & $1.81 \pm 0.32$ \\
VCL (um s') & $117.82 \pm 9.95$ & $110.15 \pm 3.89$ \\
VSL (um s')* & $38.22 \pm 1.03$ & $44.06 \pm 1.33$ \\
VAP (um s') & $80.52 \pm 2.82$ & $83.85 \pm 2.48$ \\
\hline Normal (\%)* & $81.25 \pm 1.77$ & $66.73 \pm 2.41$ \\
Coiled tail (\%)* & $17.42 \pm 1.71$ & $31.15 \pm 2.68$ \\
Other tail defects (\%) & $1.83 \pm 0.30$ & $1.96 \pm 0.31$ \\
Head defects (\%) & $1.29 \pm 0.19$ & $2.22 \pm 1.08$ \\
\hline
\end{tabular}

Legend: *Seasonal difference $(p<0.05)$.

Rev. Caatinga, Mossoró, v. 31, n. 3, p. 759 - 766, jul. - set., 2018 
The percentage of spermatozoa with a folded tail was lower $(p<0.05)$ in the reproductive season (Table 3). This morphological abnormality is prevalent in Curimba (Prochilodus lineatus) semen in the wild and it causes problems with motility and fertilization (MILIORINI et al., 2011). The most common of the other tail defects (short, heavily coiled and corrugated tail) were strongly curled and corrugated tails, both primary defects in several species (CHENOWETH, 2005). The most common of the head defects found (microcephaly, macrocephaly, degenerated head and loose head) was an loose head.

\section{CONCLUSIONS}

Use of biochemical parameters to determine the functional quality of spermatozoa has been encouraged as it is a fast, cheap and easily standardized approach. For these reasons biochemical analysis of semen offered a costeffective method of evaluating the quality of fish semen inside and outside the reproductive season.

Knowledge of semen quality is necessary for the success of breeding in commercial fish farms and also to advance scientific understanding. This study showed that the physical, biochemical, kinetic and morphological characteristics of the semen of captive Brazilian bocachico, Prochilodus brevis, are influenced by season. The frequency of morphological abnormalities is not relevant although the percentage of normal spermatozoa was higher in the reproductive period. The best biochemical indices of seminal quality in this species of fish are overall protein concentration and concentrations of glucose, triglyceride and calcium as these are the parameters that showed the greatest seasonal variation.

\section{ACKNOWLEDGMENT}

We thank the National Department of Drought Works, the State University of Ceará, the Federal University of Ceará and the Coordination of Improvement of Higher Level Personnel for supporting this research.

\section{REFERENCES}

ALAVI, S. M. H.; COSSON, J. Sperm motility in fishes: Effects of ions and osmotic pressure. Cell Biology International, Campinas, v. 30, n. 1, p. 114, 2006.

ALAVI, S. M. H. et al. Changes of sperm morphology, volume, density and motility and seminal plasma composition in Barbus barbus (Teleostei: Cyprinidae) during the reproductive season. Aquatic Living Research, Les Ulis, v. 21, n. 1, p. $75-80,2008$.

AQUINO-CORTEZ, A. et al. Comparação dos parâmetros espermáticos e bioquímicos do líquido prostático de cães da raça Pastor Alemão e Rottweiler. Acta Veterinaria Brasilica, Mossoró, v. 8, n. 2, p. 124-125, 2014.

ARAMLI, M. S. et al. Study of sperm concentration, seminal plasma composition and their physiological correlation in the persian sturgeon, Acipenser persicus. Reproduction in Domestic Animals, Linkoping, v. 48, n. 6, p. 1013-1018, 2013.

ARAÚJO, S. A.; GURGEL, H. C. B. Aspectos da biologia de Prochilodus cearensis (Steindachner, 1911) (Characiformes, Prochilodontidae) no açude Itans/Caicó, Rio Grande do Norte. Revista Brasileira de Zootecnia, Viçosa, v. 4, n. 1, p. 85-96, 2002.

BEER-LJUBIC, B. et al. Cholesterol concentration in seminal plasma as a predictive tool for quality semen evaluation. Theriogenology, New York, v. 72 , n. 8, p. 1132-1140, 2009.

BILLARD, R. Short-term preservation of sperm under oxygen atmosphere in rainbow trout, Salmo gairdneri. Aquaculture, London, v. 23, n. 1, p. $287-$ 293, 1981 .

CHELLAPPA, S. et al. Reproductive seasonality of the fish fauna and limnoecology of semi-arid Brazilian reservoirs. Limnologica, Essen, v. 39, n. 4, p. 325-329, 2009.

CHENOWETH, P. J. Genetic sperm defects. Theriogenology, New York, v. 64, n. 3, p. 457-468, 2005.

FONTENELE, O. Contribuição para o conhecimento da biologia da Curimatã pacu, Prochilodus argenteus Spix in Spix \& Agassiz (Pisces: Characidae, Prochilodontinae). Coletânea de Trabalhos Técnicos. Pesca e Piscicultura. Ministério do Interior. DNOCS. p. 215-231, 1982.

GOLPOUR, A. et al. Changes of sperm quality parameters in Caspian roach (Rutilus rutilus caspicus) during spawning migration. Czech Journal of Animal Science, Prague, v. 58, n. 3, p. 117-124, 2013.

GUASTI, P. N. et al. Componentes do plasma seminal e sua influência sobre a criopreservação e fertilidade de espermatozoides equinos. Veterinária e Zootecnia, Botucatu, v. 19, n. 2, p. 169-180, 2012. 
GUEDES, R. L. et al. Série temporal de precipitação mensal de Fortaleza, Brasil: Comparação entre observações e dados de reanálise do NCEP/NCAR. Revista Brasileira de Meteorologia, São José dos Campos, v. 20, n. 1, p. 83-92, 2005.

GURGEL, L. L. et al. Reproductive ecology of Prochilodus brevis an endemic fish from the semiarid region of Brazil. Scientific World Journal (Ecology Domain), London, v. 2012, n. 1, p. 1-7, 2012.

HALIMI, M. et al. Quantitive characteristics and chemical composition in Caspian Roach (Rutilus rutilus caspicus) sperm. Iranian Journal Fish Science, Tehran, v. 13, n. 1, p. 81-90, 2014.

KAYA, A. et al. Influence of ejaculation frequency on sperm characteristics, ionic composition and enzymatic activity of seminal plasma in rams. Small Ruminant Research, Bet Dagan, v. 44, n. 2, p. 153158, 2002.

LAHNSTEINER, F. et al. Energy resources of spermatozoa of the rainbow trout, Onchorhynchus mykiss (Pisces, Teleostei). Reproduction Nutrition Development, Cambridge, v. 33, n. 4, p. 349-360, 1993.

LAHNSTEINER, F. et al. Seminal plasma proteins prolong the viability of rainbow trout (Oncorynchus mykiss) spermatozoa. Theriogenology, New York, v. 62 , n. 5 , p. $801-808,2004$.

LAHNSTEINER, F. et al. Fatty acids of rainbow trout (Oncorhynchus mykiss) semen: composition and effects on sperm functionality. Aquaculture, London, v. 298, n. 1, p. 118-124, 2009.

LEITE, L. V. et al. Determinação da dose inseminante e embriogênese na fertilização artificial de tambaqui (Colossoma macropomum). Arquivo Brasileiro de Medicina Veterinária e Zootecnia, Belo Horizonte, v. 65, n. 2, p. 421-429, 2013.

LOPES, J. T. et al. Avaliação de diferentes crioprotetores e taxas de diluição na criopreservação seminal de Prochilodus brevis. Revista Brasileira de Reprodução Animal, Belo Horizonte, v. 38, n. 3, p. 170-175, 2014.

MAISSE, G. Cryopreservation of fish semen: a review. Proceedings of the Refrigeration Science and Technology Conference, Refrigeration and Aquaculture. Institut International du Froid, Paris, v. 1, n. 2, p. 443-467, 1996.

MELO-MACIEL, M. A. P. Cinética espermática, criopreservação do sêmen e composição bioquímica do plasma seminal de diferentes espécies de peixes characiformes. 2015. 92 f. Tese (Doutorado em Ciências Veterinárias: Área de Concentração em Reprodução animal) Universidade Estadual do Ceará, Fortaleza, 2015.

MILIORINI, A. B. et al. Morphological classification proposal for curimba (Prochilodus lineatus) sperm damages after cryopreservation. Aquaculture Research, Oxford, v. 42, n. 1, p. 177 187,2011

MORALES, J. C. Acuicultura marina animal. 2. ed. Madrid, ES: Ediciones Mundi-Prensa, 1986. 670 p.

MOURA, Í. J. M. et al. Caracterização dos períodos seco e chuvoso da cidade de Fortaleza (CE). Ciência e Natura, Santa Maria, v. 37, s/n., p. 03-07, 2015.

NASCIMENTO, M. M. et al. Biologia reprodutiva do curimatã comum, Prochilodus brevis (Characiformes: Prochilodontidae) no açude Marechal Dutra, Rio Grande do Norte, Brasil. Biota Amazônia, Amapá, v. 2, n. 2, p. 31-43, 2012.

NUNES, L. T. et al. Cryopreservation of Prochilodus brevis semen: freezing media and thawing rates. Semina, Londrina, v. 37, n. 3, p. 1643 $-1654,2016$.

RURANGWA, E. et al. The measurement of sperm motility and factors affecting sperm quality in cultured fish. Aquaculture, London, v. 234, n. 1, p. 1-28, 2004.

SECER, S. et al. Correlation between biochemical and spermatological parameters in rainbow trout (Oncorhynchus mykiss) semen. Israel Journal Aquaculture, Haifa, v. 56, n. 4, p. 274-280, 2004.

SHALIUTINA-KOLESOVA, A. et al. Protein profile of seminal plasma and functionality of spermatozoa during the reproductive season in the common carp (Cyprinus carpio) and rainbow trout (Oncorhynchus mykiss). Molecular Reproduction \& Development, New York, v. 83, n. 11, p. 968 982, 2016

SOENGAS, J. L. et al. Changes in carbohydrate metabolism in domesticated rainbow trout Oncorhynchus mykiss related to spermatogenesis. Comparative Biochemistry Physiology, Ontario, v. 105, n. 3, p. 665-671, 1993.

SOLIS-MURGAS, L. D. et al. Importância da avaliação dos parâmetros reprodutivos em peixes nativos. Revista Brasileira de Reprodução Animal, Belo Horizonte, v. 35, n. 2, p. 186-191, 2011. 
TABARES, C. J. et al. Fisiología de Ia activación del espermatozoide en peces de agua dulce. Revista Colombiana Ciências Pecuárias, Antioquia, v. 18, n. 2, p. 149-160, 2005.

TAVARES-DIAS, M.; MORAES, F. R. Biochemical parameters for Piaractus mesopotamicus, Colossoma macropomum (Characidae) and hybrid tambacu (P. mesopotamicus x C. macropomum). Ciência Animal Brasileira, Goiânia, v. 11, n. 2, p. 363-368, 2010.

VAZZOLER, A. E. A. M. Biologia da reprodução de peixes teleósteos: teoria e prática. 1. ed. Maringá, PR: NUPELIA, 1996. 169 p.

VINATEA, L. A. A. Fundamentos de Aquicultura. 1. ed. Florianópolis, SC: Ed. da UFSC. 2004. 348 p.

VIVEIROS, A. T. M. et al. Motility and fertility of the subtropical freshwater fish streaked prochilod (Prochilodus lineatus) sperm cryopreserved in powdered coconut water. Theriogenology, New York, v. 74, n. 1, p. 551-556, 2010.

WOOTTON, R. J. Ecology of Teleost Fishes. 1. ed. Ann Arbor, MI: Chapman \& Hall, 1990. 404 p.

ZANIBONI FILHO, E.; WEINGARTNER, M. Técnicas de indução da reprodução de peixes migradores. Revista Brasileira de Reprodução Animal, Belo Horizonte, v. 31, n. 3, p. 367-373, 2007. 